\section{Genetic Diversity of White Sapote (Casimiroa edulis La Llave \& Lex.) Demonstrated by Intersimple Sequence Repeat Analysis}

\author{
Masashi Yamamoto ${ }^{1}$, Takahiro Tomita, Michio Onjo, Kiyotake Ishihata, \\ Tatsuya Kubo, and Shigeto Tominaga \\ Faculty of Agriculture, Kagoshima University, Korimoto, Kagoshima \\ 890-0065, Japan
}

\section{Yoshimi Yonemoto \\ Tropical Agriculture Research Front, Japan International Research Centre for Agricultural Sciences, Ishigaki 907-0002, Japan}

Additional index words. Casimiroa tetrameria, cultivar identification, DNA analysis, intersimple sequence repeat, phylogenic relationships

\begin{abstract}
Phylogenic relationships among 31 cultivars of white sapote (Casimiroa edulis La Llave \& Lex.) were examined by intersimple sequence repeat (ISSR) analysis. Polymorphic fragments were obtained in 24 of 100 ISSR primers (UBC Set\#9, 801-900). Although 'Cuccio' and 'Florida' showed identical fragment patterns, the remaining cultivars could be distinguished from each other. The present study demonstrated the usefulness of ISSR analysis for cultivar identification and phylogenic study in white sapote.
\end{abstract}

White sapote (Casimiroa edulis La Llave \& Lex.) is an evergreen fruit tree that originated in the highlands of Mexico and Central America (Morton, 1987; Yonemoto et al., 2007). Because white sapote adapts to subtropical climate and produces attractive, relatively large and very sweet fruit, it is grown not only in the United States and Mexico, but also in warm regions of New Zealand, Australia, Israel, and Japan.

A large number of cultivars exist in white sapote because superior clones or chance seedlings were selected in California and Florida (Morton, 1987). However, the parentage of many cultivars is unknown (Brooks and Olmo, 1972), and their genetic relationships remain unclear. Recently, floral morphology, randomly amplified polymorphic DNA (RAPD), and amplified fragment length polymorphism (AFLP) markers (Yonemoto et al., 2007) have been used to characterize the white sapote germplasm.

In a previous study (Yamamoto et al., 2006), we conducted isozyme analysis for cultivar identification of white sapote. Cultivars could be classified into groups, but it was impossible to distinguish cultivars within a group from each other.

DNA analysis has been a powerful tool for cultivar identification and related studies. Intersimple sequence repeat (ISSR) analysis is a simple and quick method and its markers

Received for publication 12 Feb. 2007. Accepted for publication 15 May 2007.

${ }^{1}$ To whom reprint requests should be addressed; e-mail yamasa@agri.kagoshima-u.ac.jp. are highly polymorphic (Pradeep Reddy et al., 2002). In fruit trees as well, this technique has been used to elucidate genetic diversity and for phylogenic studies of citrus (Fang and Roose, 1997; Fang et al., 1997) and grapes (Moreno et al., 1998).

In the present study, we examined ISSR analysis to identify each cultivar and clarify phylogenic relationships of white sapote using our germplasm collection.

\section{Materials and Methods}

Plant material and DNA extraction. White sapote cultivars preserved at the Ibusuki Experimental Botanical Garden of the Experimental Farm, Faculty of Agriculture, Prefecture, Japan) were used. In this study, we analyzed 31 cultivars (Table 1). Total DNA was extracted from leaves according to the SDS method of Honda and Hirai (1990)

Intersimple sequence repeat analysis. Primers (UBC Set\#9, 801-900) were purchased from the University of British Columbia. Polymerase chain reactions were performed in a Gene Amp9700 (Applied Biosystems, Foster, CA) thermal cycler programmed as follows: initial heating at $94{ }^{\circ} \mathrm{C}$ for $5 \mathrm{~min}, 40$ cycles of denaturing at $94{ }^{\circ} \mathrm{C}$ for $1 \mathrm{~min}$, annealing at $52^{\circ} \mathrm{C}$ for $45 \mathrm{~s}$, extension at $72{ }^{\circ} \mathrm{C}$ for $2 \mathrm{~min}$, and a final extension of $10 \mathrm{~min}$ at $72{ }^{\circ} \mathrm{C}$. Amplified products were electrophoresed on $1.5 \%$ agarose gels and detected by staining with Mupid-Blue (Advancebio, Tokyo). The bands were recorded as 1 for present and as 0 for absent. Genetic distance Kagoshima University (Ibusuki, Kagoshima was calculated between each pair of the cultivars (Nei and Li, 1979). For phylogenic analysis, a tree was constructed with Molecular Evolutionary Genetic Analysis (MEGA, ver. 3.1, The Biodesign Institute, Tempe, AZ) software (Kumar et al., 2004) by applying the unweighted pair group method with arithmetic averages.

\section{Results and Discussion}

The sizes of almost all amplified fragments ranged from 500 to 2000 base pairs. Twenty-four of 100 primers showed a clear polymorphic fragment (Fig. 1; Table 2). There were 49 polymorphic fragments in total and 2.0 polymorphic fragments per primer on average. The number of polymorphic fragments produced by each primer ranged from one by $\# 821, \# 828, \# 844$, $\# 846, \# 848$, \#856, and \#857 to five by $\# 812$.

The dendrogram was constructed from ISSR data (Fig. 2). All cultivars except for 'Cuccio' and 'Florida' could be distinguished from each other. 'Cuccio' and 'Florida' always showed identical fragment patterns. Major cultivars for fruit production such as 'Cuccio' and 'Pike' clustered together. 'McDill' and 'Walton' were distant from the others.

The present study demonstrated the usefulness of ISSR analysis for cultivar

Table 1. White sapote cultivars used in this study and their types of flowers.

\begin{tabular}{lr}
\hline Cultivar & Flower type $^{z}$ \\
\hline Cate & I \\
Charles Early & I \\
Chestnut & I \\
Cuccio & I \\
Edgehill & II \\
Fallbrook & II \\
Florida & I \\
Fournoy & II \\
Golden Globe & II \\
Gwin & I \\
Lammertz & I \\
Lamsey Large & I \\
Malibue No. 1 & I \\
Malibue No. 3 & I \\
Maltby & III \\
Max Golden & I \\
McDill & I \\
Mexico & I \\
Michele & II \\
Nies & I \\
Ortega & II \\
Pike & I \\
Rainbow & I \\
Rixford & II \\
Salad & I \\
Selk & II \\
Vernon & II \\
Vista & II \\
Walton & II \\
White & I \\
Yellow & I \\
\hline accordng & Yong I
\end{tabular}

${ }^{\mathrm{z}}$ According to Yonemoto et al. (2001). Type I = large ovary and lacking pollen; type II = small ovary and producing pollen; type III = large ovary and producing pollen. 


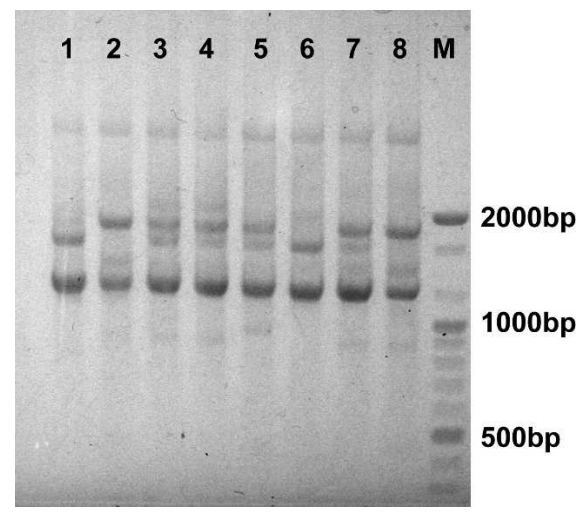

Fig. 1. DNA amplifications of white sapote cultivars using intersimple sequence repeat primer $\# 881.1=$ Rixford; $2=$ Salad; $3=$ Selk; $4=$ Vernon; $5=$ Vista; $6=$ Walton; $7=$ White $8=$ Yellow. $\mathrm{M}=$ molecular markers.

Table 2. List of primers and their sequence demonstrating polymorphic fragment in this study.

\begin{tabular}{ll}
\hline $\begin{array}{l}\text { Primer } \\
\text { number }\end{array}$ & \multicolumn{1}{c}{ Sequence $^{\mathrm{y}}$} \\
\hline 808 & AGA GAG AGA GAG AGA GC \\
812 & GAG AGA GAG AGA GAG AA \\
818 & CAC ACA CAC ACA CAC AG \\
820 & GTG TGT GTG TGT GTG TC \\
821 & GTG TGT GTG TGT GTG TT \\
823 & TCT CTC TCT CTC TCT CC \\
825 & ACA CAC ACA CAC ACA CT \\
826 & ACA CAC ACA CAC ACA CC \\
827 & ACA CAC ACA CAC ACA CG \\
828 & TGT GTG TGT GTG TGT GA \\
834 & AGA GAG AGA GAG AGA GYT \\
840 & GAG AGA GAG AGA GAG AYT \\
844 & CTC TCT CTC TCT CTC TRC \\
846 & CAC ACA CAC ACA CAC ART \\
847 & CAC ACA CAC ACA CAC ARC \\
848 & CAC ACA CAC ACA CAC ARG \\
856 & ACA CAC ACA CAC ACA CYA \\
857 & ACA CAC ACA CAC ACA CYG \\
859 & TGT GTG TGT GTG TGT GRC \\
868 & GAA GAA GAA GAA GAA GAA \\
873 & GAC AGA CAG ACA GAC A \\
881 & GGG TGG GGT GGG GTG \\
886 & VDV CTC TCT CTC TCT CT \\
895 & AGA GTT GGT AGC TCT TGA TC \\
\hline
\end{tabular}

\section{${ }^{\mathrm{z}} \mathrm{UBC}$ Set\#9, 801-900.}

${ }^{y} \mathrm{Y}=(\mathrm{C}, \mathrm{T}) ; \mathrm{R}=(\mathrm{A}, \mathrm{G}) ; \mathrm{V}=(\mathrm{A}, \mathrm{C}, \mathrm{G})$.

identification and phylogenic study in white sapote, although 'Cuccio' and 'Florida' could not be distinguished. Both cultivars have been considered identical according to morphological traits (California rare fruit growers, 1996). The present findings on ISSR analysis support this concept, although Yonemoto et al. (2007) reported that they are distinct cultivars showing close genetic relation between them using RAPD and AFLP markers.

Some cultivars such as 'Max Golden', which has hairy leaves and is called woolly leaved white sapote, has been considered a distinct species $C$. tetrameria Millsp. (Brooks and Olmo, 1972). However, 'Max Golden' was not distinct from others and clustered

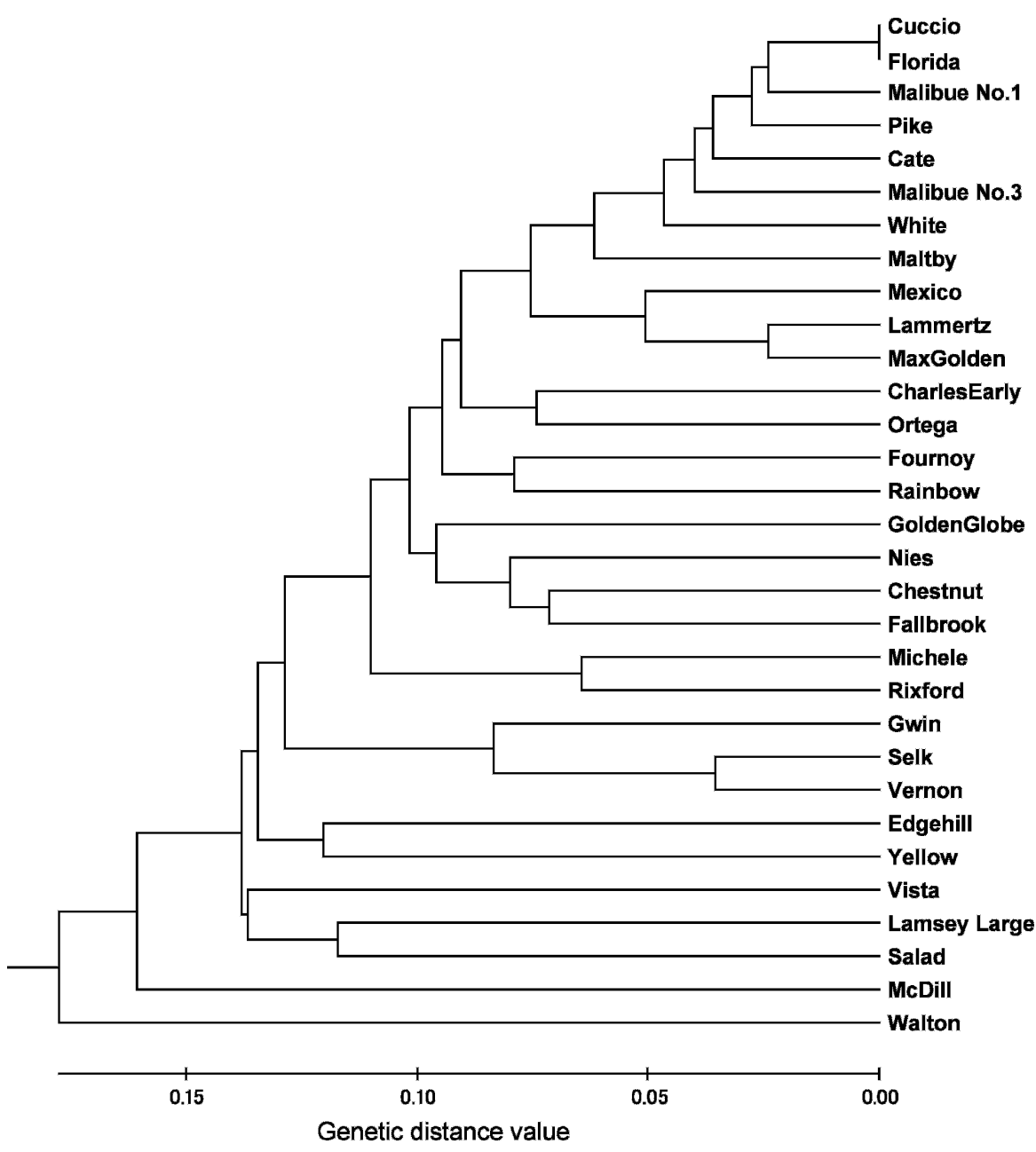

Fig. 2. Dendrogram of 31 white sapote cultivars generated by unweighted pair group method with arithmetic averages cluster analysis of intersimple sequence repeat data.

with 'Cuccio' and 'Pike' in our ISSR data. Such type of cluster was reported by Yonemoto et al. (2007) using an RAPD marker. This finding agrees with Morton (1987) who considered that woolly leaved white sapote may only be a variant of $C$. edulis.

There are three types of flowers in white sapote: type I, with a large ovary and lacking pollen; type II, with a small ovary and producing pollen; and type III, with a large ovary and producing pollen (Chambers, 1984; Yonemoto et al., 2001, 2007). In general, type I cultivars bear heavily and produce large fruit, whereas the productivity of type II cultivars is unstable (Chambers, 1984; Yonemoto et al., 2001). Table 1 shows the flower type of cultivars used in this study according to Yonemoto et al. (2001). In the cluster including 'Cuccio' and 'Max Golden', all cultivars have type I flower except for type III 'Maltby'. This indicates a close relationship among those type I cultivars. However, flower types do not correspond to the clusters formed by the remaining cultivars.

The present study demonstrated the efficiency of ISSR analysis for cultivar identification of white sapote. Moreover, ISSR analysis could provide considerable informa- tion about genetic relationships among the cultivars. These data are considered useful information for future genetic improvement of white sapote.

\section{Literature Cited}

Brooks, R.M. and H.P. Olmo. 1972. Register of new fruit and nut varieties. 2nd ed Univ. of California Press, Berkeley.

California rare fruit growers. 1996. White sapote. 5 Feb. 2003. <http//www.crfg.org/pubs/ff/ whitesapote.html>.

Chambers, R.R. 1984. White sapote varieties progress report. California Rare Fruit Growers Yrbk. 16:56-64.

Fang, D.Q. and M.L. Roose. 1997. Identification of closely related citrus cultivars with intersimple sequence repeat markers. Theor. Appl. Genet. 95:408-417.

Fang, D.Q., M.L. Roose, R.R. Kruegar, and C.T. Federici. 1997. Fingerprinting trifoliate orange germplasm accessions with isozymes, RFLPs and inter-simple sequence repeat markers. Theor. Appl. Genet. 95:211-219.

Honda, H. and A. Hirai. 1990. A simple and efficient method for identification of hybrids using nonradioactive rDNA as probe. Jpn. J. Breeding 40:339-348.

Kumar, S., K. Tamura, and M. Nei. 2004. MEGA 3: Integrated software for molecular evolutionary 
genetic analysis and sequence alignment. Brief Bioinformatics 5:150-163.

Moreno, S., J.P. Martin, and J.M. Oltiz. 1998. Intersimple sequence repeat PCR for characterization of closely related grapevine germplasm. Euphytica 101:117-125.

Morton, J.F. 1987. White sapote, p. 191-196. Fruits of warm climate. Creative Resource System, Winterville, NC.

Nei, M. and W.H. Li. 1979. Mathematical model for studying genetic variation in terms of restriction endonucleases. Proc. Natl. Acad. Sci. USA 76:5269-5273.

Pradeep Reddy, M., N. Sarla, and E.A. Siddiq. 2002. Inter simple sequence repeat (ISSR) polymorphism and its application in plant breeding. Euphytica 128:9-17.

Yamamoto, M., T. Nakagawa, M. Onjo, Y. Yonemoto, K. Ishihata, T. Kubo, and S. Tominaga. 2006. Isozyme analysis of white sapote (Casimiroa edulis La Llave \& Lex). Bul. Fac. Agr. Kagoshima Univ. 56:15-18.
Yonemoto, Y., A.K. Chowdhury, H. Kato, M.M. Macha, and H. Okuda. 2007. Characterization of white sapote (Casimiroa edulis Llave \& Lex.) germplasm using floral morphology, RAPD and AFLP markers. Scientia Hort. 112:366-375.

Yonemoto, Y., H. Higuchi, K. Ishihata, M. Ikeda, and E. Tomita. 2001. Analysis of varietal differences in floral and fruit morphology in white sapote (Casimiroa edulis Llave and Lex.). Jpn. J. Trop. Agr. 45:38-44. 